Jurnal Ilmu dan Teknologi Kesehatan

Vol 6, No 1, September 2018,

ISSN: 2338-9095 (Print)

ISSN: 2338-9109 (online)

\title{
Salat Tahajud Berpengaruh terhadap Penurunan Stres Mahasiswa
}

\author{
Azis Ritonga ${ }^{1}$, Bilqis Azizah ${ }^{2}$ \\ Poltekkes Kemenkes Jakarta III \\ azisritonga2017@gmail.com
}

\author{
Artikel history \\ Dikirim, Jun $4^{\text {th }}, 2018$ \\ Ditinjau, Aug $3^{\text {rd }}, 2018$ \\ Diterima, Aug $24^{\text {th }}, 2018$
}

\begin{abstract}
Stress is generally intended to determine the conditions that affect a person's physical or psychological state due to external pressure. A student susceptible to stress can produce student academic performance and mental health. One form of stress management by performing Tahajud Prayers. The purpose of this study was to determine the effect of tahajud prayers on stress reduction in physiotherapy students. This research is an experimental quasi research with pretest-posttest non-equivalent control two groups design, with sample consist of 15 experimental group students and 15 control group students at Physiotherapy 2nd year students at Poltekkes Kemenkes Jakarta III. Interventions given were Tahajud Prayers and the stress score was measured using a DASS-42 questionnaire. Statistical analysis t-test independents. In the experimental group the mean value of stress before was 17,2 and after the treated treatment was 6,47. As for the control group the mean value of stress before was 13 and afterwards was 16,4. Hypothesis test using independent sample t-test shows there is difference of stress value between experimental group and control $(p=0,0001)$. Tahajud Prayers has an influence on stress reduction. Tahajud Prayers is expected to be one of the stress management efforts in physiotherapy services.
\end{abstract}

Key Word: Tahajud Prayers; Stress; Student Collage

\begin{abstract}
ABSTRAK
Stres secara umum didefinisikan sebagai suatu kondisi yang mempengaruhi keadaan fisik atau psikis seseorang karena adanya tekanan dari dalam ataupun dari luar. Seorang mahasiswa mudah terkena stres sehingga dapat mengakibatkan penurunan performa akademik dan kesehatan mental mahasiswa. Salah satu bentuk penanganan stres ialah dengan melakukan Salat Tahajud. Tujuan penelitian ini adalah untuk mengetahui
\end{abstract}


pengaruh salat tahajud terhadap penurunan stres pada mahasiswa fisioterapi. Penelitian ini merupakan penelitian kuasi eksperimental dengan desain pretest-posttest nonequivalen control two groups design, dengan sampel terdiri dari 15 mahasiswa kelompok eksperimental dan 15 mahasiswa kelompok kontrol pada tingkat 2 Poltekkes Kemenkes Jakarta III Jurusan Fisioterapi. Intervensi yang diberikan adalah Salat Tahajud dan nilai stres diukur dengan menggunakan kuesioner DASS-42. Analisis statistik yang digunakan dalam penelitian ini meliputi analisis univariat dan bivariat menggunakan uji T-Test. Hasil penelitian menunjukan, pada kelompok eksperimental terjadi penurunan sress dari 17,2 menjadi 6,47 setelah Tahajud. Sedangkan pada kelompok kontrol terjadi peningkatan rata-rata stres dari 13,0 menjadi 16,4. Hasil independent sample ttest menunjukkan terdapat perbedaan nilai stres antara kelompok eksperimental dan kontrol $(p=0,0001)$. Salat Tahajud memiliki pengaruh terhadap penurunan stres. Sehingga, Salat Tahajud diharapkan dapat menjadi salah satu upaya penanganan stres di pelayanan fisioterapi.

Kata kunci: Salat Tahajud; Stres; Mahasiswa

\section{PENDAHULUAN}

Perguruan tinggi merupakan salah satu jenjang pendidikan untuk memperdalam ilmu pengetahuan, dengan tujuan untuk meningkatkan mutu Sumber Daya Manusia (SDM) (Ebtanastiti and Muis, 2014). Menurut Sudrajat yang dikutip oleh Nuzulul Rahmi, belajar di perguruan tinggi merupakan suatu pekerjaan yang berat karena menuntut upaya tidak sedikit. Hal ini dibuktikan dengan banyaknya kegiatan akademik maupun non akademik yang harus dijalani oleh mahasiswa (Rahmi, 2013). Banyaknya tugas perkuliahan, jadwal perkuliahan yang padat, ujian, manajemen waktu yang buruk dan masalah pada sosialnya serta kecemasan tidak mendapatkan pekerjaan sesudah lulus kuliah menjadi salah satu sumber stres dikalangan mahasiswa (Agolla and
Ongori, 2009)

Robbins dalam Rismalinda (2017) menjelaskan bahwa stress secara umum didefinisikan sebagai suatu kondisi yang mempengaruhi keadaan fisik atau psikis seseorang karena adanya tekanan dari dalam maupun dari luar yang dapat menggangu seseorang dalam melaksanakan kerjanya. Stres pada mahasiswa dapat disebabkan oleh kehidupan akademiknya (Legiran et al., 2015). Terdapat empat faktor penyebab stres pada mahasiswa, yaitu faktor akademik, faktor lingkungan, faktor emosi, dan faktor sosial (Navas, 2012). Menurut I Made Afryan Susane tuntutan akademik, penilaian sosial, manajemen waktu serta biaya perkuliahan dapat memicu keadaan stres pada mahasiswa (Susane, 2017).

Kondisi stres pada mahasiswa dapat 
3 Jurnal Ilmu dan Teknologi Kesehatan, Vol 6 Nomor 1, September 2018, hlm : 1 - 7

berdampak negatif stres seperti, terjadi penurunan produktifitas, sulit berkonsentrasi, penurunan kemampuan mengingat informasi, mempengaruhi pengambilan keputusan, dan terganggunya kesehatan seperti gagal jantung, tekanan darah tinggi, pusing, dan mual (Wahyuni, 2017). Sehingga, disimpulkan bahwa stres secara langsung maupun tidak, diyakini sebagai salah satu penentu performa akademik dan kesehatan mental pada mahasiswa di perkuliahan. Penanganan stres sangatlah penting untuk meningkatkan kualitas akademik mahasiswa. Umumnya, stres ditangani dengan melakukan rileksasi dan meditasi. Selain itu, penanganan dengan pendekatan agama atau biasa dikenal dengan psikoreligius dapat menjadi salah satu alternatif dalam penanganan stres yaitu dengan melakukan salat tahajud (Rismalinda, 2017).

Salat tahajud yang dilakukan pada malam hari memiliki manfaat baik dari sudut pandang religius maupun kesehatan, hal ini diperkuat dengan hadis yang diriwayatkan oleh Tirmidzi sebagaimana disabdakan Rasulullah SAW "salat tahajud dapat menghapus dosa, mendatangkan ketenangan, dan menghindarkan dari penyakit." (Sholeh, 2012).

Pada observasi awal yang dilakukan oleh peneliti di Poltekkes Kemenkes Jakarta III
Jurusan Fisioterapi menunjukkan bahwa beban kurikulum pada mahasiswa tingkat dua mengalami peningkatan jika dibandingkan dengan beban kurikulum pada tingkat satu. Hal ini disebabkan pada tingkat dua mahasiswa mulai dikenalkan dengan mata kuliah yang menjadi dasar dari ilmu fisioterapi, yang mana merupakan hal baru namun penting untuk individu yang menjalani perkuliahan di Jurusan Fisioterapi. Selain menjalani kegiatan akademik, mahasiswa tingkat dua juga menjalani kegiatan nonakademik seperti mengikuti kegiatan organisasi baik di dalam kampus maupun di luar kampus. Hal ini menuntun mereka untuk dapat mengatur waktu dengan baik antara kegiatan akademik maupun non-akademik. Selain tuntutan dalam mengatur waktu, mahasiswa yang aktif dalam kegiatan organisasi sering kali mengalami tekanan akibat permasalahan di dalam organisasi tersebut.

\section{METODE}

Penelitian menggunakan pendekatan quasi eksperimental dengan rancangan pre and post test two group design untuk membutkikan pengaruh salat tahajud terhadap penurunan stres pada mahasiswa tingkat 2 di Poltekkes Kemenkes Jakarta III Jurusan Fisioterapi (Sugiyono, 2003). Teknik sampling yang digunakan adalah purposive sampling 
yaitu teknik penentuan sampel dengan pertimbangan tertentu (Sugiyono, 2001). Penelitian ini akan dilaksanakan di Kampus Poltekkes Kemenkes Jakarta III Jurusan Fisioterapi bulan April sampai dengan Mei 2018. Sampel terdiri dari 15 mahasiswa kelompok eksperimental dan 15 mahasiswa kelompok kontrol yaitu mahasiswa tingkat 2 Poltekkes Kemenkes Jakarta III Jurusan Fisioterapi, dengan kriteria inklusi, yaitu: mahasiswa tidak pernah/jarang melakukan sholat tahajud kecuali saat bulan Ramadhan (shalat taraweh). Intervensi yang diberikan adalah Salat Tahajud dan nilai stres diukur dengan menggunakan kuesioner DASS-42 (Depression, Anxiety, Stress Scale 42). Untuk membandingkan perbedaan stres antara kelompok kontrol dan perlakuan digunakan uji independent $t$ test setelah dilakukan uji uji normalitas.

\section{HASIL DAN PEMBAHASAN}

Tabel 1. Uji Normalitas dan Homogenitas Varians

\begin{tabular}{lcccc}
\hline \multicolumn{1}{c}{ Jenis Kelompok } & Skewness & $\begin{array}{c}\text { Standar } \\
\text { error }\end{array}$ & $\begin{array}{c}\text { Skewness/Stand } \\
\text { ar error }\end{array}$ & P value* \\
\hline Kontrol & 0,733 & 0,58 & 1,26 & 0,60 \\
\cline { 1 - 3 } Perlakuan & $-0,507$ & 0,58 & 0,87 & \\
\cline { 1 - 3 } & & & &
\end{tabular}

*uji homogenitas dengan Levene's test

Berdasarkan tabel 1 hasil uji normalitas nilai stres sebelum dan sesudah dengan menggunakan nilai Skewness dan standar error didapatkan hasil $\leq 2$ pada data kelompok eksperimental maupun kontrol. Maka dapat disimpulkan bahwa hasil data pada penelitian ini berasal dari populasi yang berdistribusi normal Berdasarkan uji homogen dengan uji levene's nilai sign $=0,60$, artinya data adalah homogen.

Tabel 2. Pengaruh S alat Tahajud terhadap Penurunan Stres Mahasiswa

\begin{tabular}{lcccc}
\hline Kelompok & $\begin{array}{c}\text { Sebelum } \\
\mathrm{X} \pm \mathrm{SD}\end{array}$ & $\begin{array}{c}\text { Sesudah } \\
\mathrm{X} \pm \mathrm{SD}\end{array}$ & $\begin{array}{c}\text { Penurunan } \\
\text { Stres }\end{array}$ & P value \\
\cline { 1 - 4 } Kontrol & $13 \pm 5,66$ & $16,4 \pm 6,43$ & 3,4 & \multirow{2}{*}{0,000} \\
\cline { 1 - 3 } Perlakuan & $17,2 \pm 6,08$ & $6,47 \pm 3,54$ & $-10,73$ &
\end{tabular}


5 Jurnal Ilmu dan Teknologi Kesehatan, Vol 6 Nomor 1, September 2018, hlm : 1 - 7

Berdasarkan uji pengaruh Independent Sample T-test didapatkan nilai sign = 0,000, artinya, ada perbedaan antara kelompok kontrol dan kelompok perlakuan terhadap intervensi. Hasil penelitian menunjukan, pada kelompok eksperimental terjadi penurunan sress dari 17,2 menjadi 6,47 setelah Tahajud. Sedangkan pada kelompok kontrol terjadi peningkatan rata-rata stres dari 13,0 menjadi 16,4. Hasil ui statistic dengan $\mathrm{t}$ test independen menunjukkan ada perbedaan rata-rata stress antara kelompok intervensi dan kelompok kontrol. Sehingga disimpulkan bahwa Tahajud efektif untuk menurunkan stress mahasiswa.

Penelitian ini sejalan dengan teori yang dikemukakan oleh beberapa ahli terkait hubungan Salat Tahajud dengan penurunan nilai stres antara lain dilihat dari gerakan Salat Tahajud yang memiliki manfaat untuk melancarkan peredaran darah serta relaksasi (El-Sutha, 2016). Penanganan stres menurut Rismalinda (2017) ialah dengan menggunakan pendekatan relaksasi dan meditasi yaitu salah satunya salat tahajud. Salat tahajud merupakan sarana meditasi tertinggi apabila dilakukan dengan ketenangan hati serta mencapai kekhusyukan (Yusuf, 2008). Khususnya saat melakukan gerakan sujud posisi jantung akan lebih tinggi dari otak, hal ini dapat menyebabkan aliran darah yang menuju ke otak akan lancar (El-Sutha, 2016). Apabila aliran darah ke otak tercukupi maka dapat memicu sekresi hormon serotonin, endorphin, dopamin, dan oksitosin sehingga terjadinya penurunan stres secara fisiologis (Haruyama, 2015).

Selain itu, dengan melakukan salat tahajud pada dini hari otak khususnya pada bagian hipotalamus yang berfungsi mengatur emosi dan perilaku dapat menerima asupan darah kaya oksigen lebih banyak. Sebagaimana yang kita ketahui bahwa oksigen memiliki peran penting bagi kehidupan manusia (Semedi and Hardiono, 2012). Semua sel di tubuh memerlukan pasokan oksigen yang memadai untuk proses metabolisme yang menghasilkan energi. Salah satu sel di tubuh yang sangat bergantung dengan pasokan oksigen secara terus-menerus adalah sel di otak (Sherwood, 2014). Pada pagi hari tekanan oksigen dan keasaman darah tinggi, serta kemampuan hemoglobin mengikat oksigen meningkat (Ganong, 2003).

Teori lain yang mendukung salat tahajud dapat menurunkan stres dilihat dari pengaruh sistem fisiologi, yaitu pada pola kehidupan manusia yang dikenal dengan irama sirkadian diurnal. Irama sirkadian merupakan siklus 24 jam dalam tubuh 
yang mengalami fluktuasi berupa temperatur, kemampuan untuk bangun, aktivitas lambung, denyut jantung, tekanan darah dan kadar hormon (Saftarina et al., 2014). Menurut Reichlin, gangguan irama sirkadian akan mendatangkan stress yang ditandai dengan peningkatan ACTH. Dengan melakukan Salat Tahajud di malam hari, irama tubuh ini akan berubah menjadi nokturnal yang menyebabkan perubahan perilaku pada sistem saraf pusat dengan tujuan agar dapat beradaptasi dengan irama sirkadian (Sholeh, 2012).

\section{SIMPULAN}

Salat Tahajud memiliki pengaruh terhadap penurunan stres Mahasiswa tingkat 2 Di Poltekkes Kemenkes Jakarta III Jurusan Fisioterapi. Bagi responden diharapkan tetap menjalankan Salat Tahajud sehingga dapat menurunkan stres yang disebabkan oleh tuntutan dari dalam diri maupun dari luar seperti akademik dan lingkungan

\section{DAFTAR RUJUKAN}

Agolla, J.E and Ongori, H. 2009. An assessment of academic stress among undergraduate students: The case of University of Botswana. Educational Research and Review. 4(2). pp. 63-70. doi:10.1036/0071466339.
Ebtanastiti, Dyah Fajar and Muis, Tamsil. 2014. Survei Pilihan Karir Mahasiswa Fakultas Matematika Dan Ilmu Pengetahuan Alam Universitas Negeri Surabaya. Jurnal Bimbingan Konseling. 04(03). pp. 1-10.

El-Sutha, Saiful Hadi. 2016. Shalat Samudra Hikmah. Jakarta: WahyuQolbu.

Ganong, William Francis. 2003. Buku Ajar: Fisiologi Kedokteran. Jakarta: EGC.

Haruyama, S. P. 2011. Statistik Kesehatan. Jakarta: Rajawali Pers.

Legiran A, Bellinawati M.Z., Nedya. 2015. Faktor Resiko Stress Dan Perbedaan Pada Mahasiswa Berbagai Angkatan Di Faklultas Kedokteran Unversitas Muhammadiyah Palembang. 2(2). pp. 197-203.

Navas, S. 2012. Stress among Medical Students. KERALA MEDICAL JOURNAL. 5(2). pp. 34-37.

Rahmi N. 2013. Hubungan Tingkat Stres Dengan Prestasi Belajar Mahasiswa Tingkat II Prodi D-III Kebidanan Banda Aceh Jurusan Kebidanan Poltekkes Kemenkes NAD TA. 2011/2012. 2(1). pp. 6676.

Rismalinda. 2017. Psikologi Kesehatan. Jakarta: Trans Info Media.

Saftarina, F., Wintoko, Handayani, RW. 2014. The Corelation of Anxiety Levels with Shift Work Inpatient Installasion Nurses Working in Shift and Non-shift in Dr. H. Abdul 
7 Jurnal Ilmu dan Teknologi Kesehatan, Vol 6 Nomor 1, September 2018, hlm : 1 - 7

Moeloek Public Hospital in Bandar Lampung. 01. pp. 142-150.

Semedi, Pujo B., Hardiono. 2012. Pemantauan Oksigenasi. Universitas Airlangga. 2. pp. 85-93.

Sholeh, M. 2012. Terapi shalat Tahajud: Menyembuhkan Berbagai Penyakit . Jakarta: Nourabooks.

Sherwood, L. 2014. Fisiologi Manusia: dari sel ke system. Jakarta: EGC.

Sugiyono. 2009. Statistika untuk Penelitian. Jakarta: AlfaBeta.

Susane, Afryan IM. 2017. Hubungan Tingkat Stres Terhadap Motivasi Mahasiswa Dalam
Menyelesaikan Skripsi Pada Mahasiswa Tingkat Akhi r Di Fakultas Kedokteran Universitas Lampung. JURNAL KEDOKTERAN DAN KESEHATAN.

Wahyuni, Esa N. 2017. Mengelola Stres Dengan Pendekatan Cognitive Behavior Modification (Studi Eksperimen Pada Mahasiswa Baru Pendidikan Agama Islam (PAI) Fakultas Ilmu Tarbiyah dan Keguruan UIN Maliki Malang). Tadrib: Jurnal Pendidikan Agama Islam. 3(1). p. 98. doi: 10.19109/Tadrib.v3i1.1385.

Yusuf, Nanang Qosim. 2008. The Heart of 7 Awareness 